\author{
Ewa Szafrańska, Agnieszka Michalska-Żyła \\ Uniwersytet Łódzki \\ e-mails: ewa.szafranska@geo.uni.lodz.pl; agnieszka.michalska-zyla@uni.lodz.pl
}

\title{
DLACZEGO LÓDŹ? ATRAKCYJNOŚĆ MIGRACYJNA MIASTA W UJĘCIU JAKOŚCIOWYM
}

\section{WHY LÓDŹ? MIGRATION ATTRACTIVENESS OF THE CITY IN QUALITATIVE APPROACH}

DOI: $10.15611 /$ pn.2018.534.02

\begin{abstract}
Streszczenie: Relatywnie niska atrakcyjność migracyjna Łodzi, pogłębiająca niekorzystną sytuację demograficzną miasta, skłoniła do sformułowania pytania kim są osoby, które decydują się związać swoje losy z miastem oraz jakie są główne powody ich osiedleńczych decyzji. Empiryczną podstawą artykułu są badania przeprowadzone w 2016 r. wśród „nowych łodzian”. Podjęta problematyka mieści się w szerszej perspektywie badań nad atrakcyjnością migracyjną miast lecz ujęta została w sposób jakościowy (z wykorzystaniem techniki indywidualnego wywiadu pogłębionego). Rezultaty badania wskazały, że do głównych powodów osiedlenia się w mieście należą: po pierwsze funkcjonowanie najważniejszych kompleksów instytucjonalnych takich jak rynek pracy, edukacja, opieka zdrowotna oraz usługi dla ludności; po drugie względy osobiste i rodzinne; oraz po trzecie podjęcie studiów oraz znalezienie tu pierwszej pracy.
\end{abstract}

Słowa kluczowe: atrakcyjność migracyjna, powody migracji, Łódź, warunki życia, badania jakościowe.

Summary: The relatively low migration attractiveness of Łódź, which deepens the unfavourable demographic situation of the city, has become an inspiration to formulate the questions who the people who decide to settle in the city are and what the main reasons of their decisions are. The empirical basis of the article is research conducted in 2016 among the "new Łódź residents". The issue covered fall into the wider perspective of research on the migration attractiveness of cities, but it has been conducted using a qualitative approach (using the technique Individual in-Depth Interviews). The results of the study indicate that the main reasons for settling in the city are: first, the functioning of the most important institutional complexes, such as the labour market, education, health care and services for the population; second, personal and family reasons, including finding a life partner in Łódź or the desire to live close to relatives, and third, study and the first job there.

Keywords: migration attractiveness, reasons for migration, Łódź, living conditions, qualitative approach. 


\section{Wstęp}

Jeszcze do niedawna głównym celem migracji wewnętrznych były duże miasta, a głównym czynnikiem przyciągającym był rozwój przemysłu. To właśnie dzięki przemysłowi Łódź w XIX i XX w. stała się swoistym fenomenem migracyjnym, osiągając w krótkim czasie rekordowy w skali europejskiej wzrost liczby ludności i stając się drugim co do wielkości miastem w Polsce. Przyrost ludności zapoczątkowany w I połowie XIX w. osiągnął swój punkt kulminacyjny w latach osiemdziesiątych XX w., kiedy to liczba mieszkańców Łodzi sięgała prawie 850 tys. [Szukalski 2012]. Sytuacja zmieniła się diametralnie pod koniec XX w., kiedy wraz z transformacją ustrojową i towarzyszącym jej załamaniem bazy gospodarczej miasta, jaką stanowił przemysł włókienniczy, rozpoczął się proces znacznego ubytku liczby ludności. Dziś Łódź jest miastem o jednym z najwyższych wskaźników depopulacji wśród wszystkich dużych miast Polski. W ciągu ostatnich trzech dekad miasto utraciło ponad 150 tys. mieszkańców, tracąc przy tym (w 2007 r.) status drugiego co do wielkości miasta w Polsce na rzecz Krakowa. W konsekwencji tej straty, tak jak fenomenalny był wzrost ludności miasta w XIX i XX w., tak spektakularny, na tle największych miast Polski, był jej spadek na przełomie XX i XXI w. W stosunku do maksymalnej liczby ludności odnotowanej w 1984 r. (848 tys.), ta odnotowana w 2015 r. była niższa w przypadku Łodzi aż o 18\%, podczas gdy w Poznaniu, Wrocławiu i Krakowie ubytek ludności w tym czasie nie przekroczył kilku punktów procentowych.

Główną przyczyną niekorzystnych zmian ludnościowych był przede wszystkim ubytek naturalny wyrażony niekorzystną proporcją liczy urodzeń i zgonów. W porównaniu z innymi wielkimi miastami w Łodzi przychodzi na świat najmniej dzieci, a umieralność łodzian przed 50. rokiem życia jest dwukrotnie wyższa. To decyduje że sytuacja miasta w kwestii przyrostu naturalnego jest wręcz tragiczna [Szukalski 2012]. Niekorzystnych dla miasta tendencji depopulacyjnych dopełniają procesy migracyjne, choć ich rzeczywisty wpływ na ubytek mieszkańców jest niewielki. Największym problemem miasta jest bowiem nie tyle odpływ migracyjny ludności (od kilku lat nie przekraczający 1000 mieszkańców rocznie), ile bardzo mały jej napływ, nawet o 50-60\% niższy niż ten odnotowywany w innych dużych miastach Polski [Kałuża-Kopias 2014]. Jak wskazuje E. Kryńska [2015], spadek liczby ludności dużego miasta o 20-30\% lub więcej prowadzi do poważnych konsekwencji społecznych, gospodarczych i przestrzennych. Przede wszystkim przyczynia się do utraty kapitału ludzkiego, a jeśli dotyczy przedstawicieli tych kategorii, które w literaturze określane są klasą kreatywną [Landry, Bianchini 1995; Florida 2002], czyli młodych, wysoko wykwalifikowanych i dobrze wykształconych mieszkańców, znacznie ogranicza potencjał i atrakcyjność miasta. Zjawisko to, w migracjach międzynarodowych określane „drenażem mózgów” (brain drain) ${ }^{1}$, w konsekwencji

${ }^{1}$ Pojęcie to, po raz pierwszy użyte na początku lat 60. ubiegłego wieku, współcześnie, w dobie globalizacji coraz częściej ustępuje pojęciom „wymiana mózgów” (brain exchange) lub też ich „,cyrkulacja" (brain circulation) [Tarasiewicz 2013]. 
ogranicza możliwości oraz tempo rozwoju miasta, co z kolei rzutuje zarówno na stopień zaspokojenia potrzeb mieszkańców, jak i możliwości realizacji przez nich swoich aspiracji [Kryńska 2015].

Atrakcyjności migracyjnej Łodzi nie sprzyja także sytuacja na rynku pracy, stanowiąca zgodnie z wieloma klasycznymi modelami migracji (zob. [Górny, Kaczmarczyk 2003]) jeden z głównych czynników przyciągających do miast. Łódzki rynek pracy, mimo poprawy odnotowanej w ostatnich latach (na koniec 2016 r. stopa bezrobocia wynosiła tu 7,9\%), od początku transformacji ustrojowej był bowiem w znacznie gorszej kondycji niż w innych dużych miastach Polski. Dla porównania w 2002 r. stopa bezrobocia w Łodzi wynosiła $18,8 \%$, podczas gdy w Warszawie 6,2\%, w Krakowie 8,4\%, w Poznaniu 6,9\%, a we Wrocławiu 12,3\% [GUS 2002]. Dekadę później (w 2012 r.), mimo zdecydowanej poprawy (12\%), wciąż co najmniej dwukrotnie przewyższała tę odnotowaną w pozostałych największych miastach Polski [GUS 2014].

Omówiona sytuacja niewątpliwie przyczynia się do dystansowania się Łodzi w stosunku do innych ośrodków metropolitalnych w kraju. Sytuację tę potwierdzają badania prowadzone przez firmę Price Waterhouse Coopers w latach 2011 i 2015 [PWC 2011; 2015]. Oba badania pokazały, że pod względem poziomu siedmiu badanych „kapitałów”, Łódź ma jedną z najniższych pozycji w grupie badanych 12 miast, a jej charakterystyka zbliżona jest do miast zdecydowanie mniejszych, takich jak Bydgoszcz, Szczecin czy Białystok, niż ponad 500-tysięcznych, takich jak Warszawa, Kraków, Poznań czy Wrocław. Szczególnie nisko oceniano zwłaszcza wizerunek Łodzi, nadal kojarzonej z upadłym przemysłem, zaniedbaniem i problemami rozwoju, jak i niską jakością życia i zamieszkiwania (zob. także [Czapiński, Panek 2015; Michalska-Żyła 2014]). Zwraca się przy tym uwagę, że dostępność, a także jakość działania określonych instytucji w znacznym stopniu przesądzają o jakości życia danej społeczności. Ta z kolei ma istotne znaczenie dla poczucia przywiązania do lokalnej społeczności [Brehm i in. 2004] i chęci podtrzymywania roli jej członka, osłabiając tym samym tendencje migracyjne. Liczba i jakość instytucji oraz udogodnień lokalnych (amenities) jest istotnym czynnikiem wpływającym na ocenę miejscowości zamieszkania jako dogodnego, atrakcyjnego miejsca do życia, stanowiąc przy tym wskaźnik rozwoju danej społeczności [Florida 2002; Clark 2004; Besser i in. 2009].

Warto jednak zauważyć, że mimo niewielkiego i wciąż ujemnego salda migracji, każdego roku odnotowuje się w Łodzi nowe zameldowania. W kontekście omówionych powyżej niekorzystnych uwarunkowań atrakcyjności migracyjnej Łodzi powstaje zatem pytanie: kim są osoby, które decydują się związać swoje losy z tym miastem oraz, co wydaje się dużo bardziej interesujące, jakie są główne powody ich osiedleńczych decyzji. Niniejszy tekst stanowi próbę odpowiedzi na tak sformułowane pytania.

\footnotetext{
${ }^{2}$ Badanie obejmowało następujące rodzaje „kapitałów” decydujących o potencjale rozwojowym miasta: instytucje, ludzi, inwestycje, jakość życia, wizerunek, infrastrukturę i finanse.
} 


\section{Metoda badań i materiały źródłowe}

Podjęta problematyka mieści się w szerszej perspektywie badań nad atrakcyjnością migracyjną miast (zob. np. [Kupiszewski 2002; Kałuża-Kopias 2010; 2014; Kryńska 2015]). Zaznaczyć jednak należy, że przeprowadzone badanie oraz jego rezultaty mają charakter jakościowy, stąd powszechnie przyjęta definicja atrakcyjności migracyjnej rozumianej ilościowo, w postaci relacji salda migracji do obrotu migracyjnego [Łabędzki 2009; Kałuża-Kopias 2014], nie znalazła tu zastosowania. W opracowaniu skupiono się na powodach wyboru Łodzi jako miejsca do życia, traktując je jako ważny aspekt atrakcyjności migracyjnej miasta. Celem badań było bowiem ustalenie, jakie czynniki przyciągają do Łodzi, a równocześnie wypychają z poprzednich miejsc zamieszkania. Dopełnieniem analizy było prześledzenie, jak nowi łodzianie oceniają miasto w kontekście obecnych warunków życia w nim. W konsekwencji zmierzało to do określenia głównych atutów miasta, które mogą decydować o jego atrakcyjności zarówno dla nowych, jak i dla obecnych mieszkańców, a także elementów, które stanowić mogą bariery migracji do miasta.

$\mathrm{W}$ badaniach przyjęto, za jedną z klasycznych już teorii przyczyn migracji tzw. push-pull theory E. Lee [1966] oraz późniejszym modelem zachowań migracyjnych G. Hugo [1982], że decyzja migracyjna podejmowana jest na podstawie porównania cech miejsca pochodzenia i lokalizacji docelowej oraz zbioru czynników, które mogą bądź sprzyjać, bądź też zniechęcać do danego obszaru [Lee 1966] oraz że migracja jest skutkiem decyzji, która jest pozytywna wówczas, gdy oczekiwane korzyści z tytułu mobilności przewyższają jej koszty [Hugo 1982].

Empiryczną podstawą niniejszego artykułu są badania jakościowe przeprowadzone na zlecenie Urzędu Miasta Łodzi w 2016 r. Ich głównym celem było ustalenie, kim są nowi łodzianie oraz jakie przyczyny zdecydowały o ich osiedleniu się w mieście na stałe. Intencją zleceniodawcy było przede wszystkim uzyskanie wiedzy, która pozwoli na bardziej efektywną promocję miasta (zewnętrzną oraz wewnętrzną), a w konsekwencji przyciągnięcie do miasta nowych mieszkańców oraz zapobieżenie odpływowi obecnych ${ }^{3}$.

Badani zostali dobrani dwuetapowo. Pierwszym etapem była analiza niepublikowanych danych z ewidencji ludności dotyczących zameldowań w Łodzi w dwóch latach poprzedzających badanie (2014 i 2015), na podstawie których wyodrębniono określone kategorie migrantów, biorąc pod uwagę ich wiek oraz pochodzenie terytorialne. Następnie z każdej z wyodrębnionych grup wieku oraz pochodzenia dokonano doboru respondentów, tak aby wewnętrzne proporcje próby odzwierciedlały rzeczywistą strukturę migrantów. W badaniu uczestniczyli dorośli mieszkańcy Łodzi należący do czterech kohort wiekowych wyodrębnionych w oparciu o kryterium

\footnotetext{
${ }^{3}$ Badania przeprowadzone zostały przez firmę Media-tor na zlecenie Wydziału Strategii Miasta. W związku z tym, że jedna z autorek artykułu brała udział w tworzeniu scenariusza wywiadu oraz opracowaniu wyników badań, zleceniodawca wyraził zgodę na ich publikację w celach naukowych.
} 
funkcjonalno-ekonomiczne (19-25 lat, 26-35 lat, 36-60 lat oraz 61 i więcej lat), reprezentujący trzy kategorie obszarów pochodzenia: Łódzki Obszar Metropolitalny (ŁOM), województwo łódzkie oraz spoza województwa. Badania przeprowadzono w oparciu o technikę wywiadu swobodnego ze standaryzowaną listą poszukiwanych informacji, na podstawie której skonstruowano autorski scenariusz wywiadu. Ogółem zrealizowano 32 wywiady.

Dane będące podstawą doboru respondentów pokazały, że w latach 2014 i 2015 w Łodzi zameldowało się 5540 osób, odpowiednio 2738 i 2822. Bliższa analiza struktury wieku i pochodzenia terytorialnego tej zbiorowości pokazała, że, podobnie jak w latach poprzednich, dominowały w niej osoby w wieku 26-35 lat (prawie $60 \%$ ). Około $25 \%$ osób pochodziło z obszaru Łódzkiego Obszaru Metropolitalnego, $35 \%$ z bardziej oddalonych powiatów województwa łódzkiego, a 40\% spoza województwa. Wśród tych ostatnich, największa liczba nowych łodzian pochodziła z województw ościennych (mazowieckie, wielkopolskie), nieodległego świętokrzyskiego, które od wielu lat stanowi zaplecze migracyjne Łodzi oraz kujawsko-pomorskiego.

\section{Przyczyny migracji do Łodzi}

Pierwszym elementem analizy było ustalenie głównych przyczyn osiedlenia się w Łodzi, jakie wyłaniały się z wypowiedzi badanych. W literaturze przedmiotu wśród podstawowych przyczyn migracji najczęściej wymienia się przyczyny zarobkowe, rodzinne, edukacyjne, mieszkaniowe, sentymentalne, polityczne i przymusowe [Łabędzki 2009]. Poza dwiema ostatnimi przyczynami, które z reguły występują w przypadku migracji zewnętrznych, pozostałe wystąpiły w wypowiedziach badanych.

Jednym z głównych powodów przeprowadzki do Łodzi, co oczywiste, były argumenty związane z podjęciem pracy na terenie miasta. Wybór Łodzi jako miejsca zamieszkania podyktowany był więc niekiedy znalezieniem tu pracy, ale nie zawsze miało to charakter planowy. „Zbieg okoliczności, że mieszkam w Łodzi. To była moja pierwsza oferta pracy zaraz po studiach [w Krakowie - przyp. aut.]. Podjęłam decyzję, że przyjmuję tę pracę i tak zostałam. A potem mój chłopak znalazł tu pracę" (K., 27 1., wieś w woj. świętokrzyskim). Zdarzało się jednak i tak, że wybór Łodzi jako miejsca pracy i zamieszkania był celowy. Badani zachęceni rekomendacjami innych osób, które znajdowały pracę w Łodzi, postanowili także spróbować. Najczęściej były to osoby pochodzące z obszarów, w których sytuacja na rynku pracy jest trudna. „Dużo znajomych się do Łodzi przeprowadzało i znajdowali tu pracę, i ja też przy jechałem do pracy. Bo w mojej miejscowości nie ma pracy" (M., 401., małe miasto w ŁOM). Celowym wyborem Łodzi jako miejsca pracy i zamieszkania kierowali się przede wszystkim ci, którzy postrzegali łódzki rynek pracy jako relatywnie lepiej funkcjonujący i dający możliwość znalezienia pracy w zawodzie. Jak podkreśla jeden z respondentów: „U mnie, tam gdzie mieszkałem, znalezienie pracy w zawodzie praktycznie było niemożliwe” (M., 33 1., wieś w woj. warm.-maz.). Po- 
wodzenie na łódzkim rynku pracy było także jednym z najistotniejszych motywów związania z miastem swoich losów, nawet dla osób pochodzących z nieodległych miejscowości. Sytuacje tę doskonale ilustruje poniższa wypowiedź: „Znalazłam tu pracę i najpierw dojeżdżałam ale potem uznałam, że to strata czasu i zaczęłam wynajmować mieszkanie w Łodzi, a potem kupiłam” (K., 27 1., małe miasto w ŁOM).

$\mathrm{Z}$ opinii badanych wyłania się zatem obraz miasta, które stwarza nowo przybyłym możliwości zawodowe. Warto zwrócić uwagę, że osoby znajdujące tu pracę pochodziły głównie ze wsi lub małych miejscowości, co może wskazywać, że łódzki rynek pracy postrzegany był jako atrakcyjny w porównaniu z tymi funkcjonującymi na obszarach wiejskich lub w małych miastach, których małe zróżnicowanie nie zapewniało możliwości znalezienia pracy, zwłaszcza w określonym zawodzie. Nie był natomiast atrakcyjny dla mieszkańców innych dużych ośrodków miejskich, co jednakże wydaje się oczywiste w świetle obiektywnych danych o rynkach pracy w innych dużych miastach Polski.

Drugim głównym powodem osiedlenia się w Łodzi na stałe, wymienianym równie często jak praca, były względy rodzinne, pośród których dominowało zamieszkanie tu z żoną/mężem po zawarciu związku małżeńskiego. Jak relacjonuje jeden $\mathrm{z}$ respondentów ,powodem przeprowadzki była żona, tzn. miłość do żony. Poznaliśmy się w górach i tak się zaczęło, przyjechałem tu i teraz mamy córkę" (M., 31 1., średnie miasto w woj. małopolskim). Na tę samą przyczynę przeprowadzki wskazuje inna respondentka: „Główny powód to wyjście za mąż. Mąż tutaj mieszkał i ja też zdecydowałam się zamieszkać. Spotkaliśmy się przypadkiem, tam gdzie studiowaliśmy" [nie w Łodzi - przyp. aut.] (K., 37 1., średnie miasto w woj. łódzkim). Przyczyny rodzinne nie ograniczały się jednak wyłącznie do tych związanych z zawarciem związku małżeńskiego z partnerem/partnerką mieszkańcem Łodzi i przeprowadzką do niej / do niego. W grupie osób najstarszych znaleźli się dziadkowie, którzy przeprowadzili się lub też powrócili do miasta, po okresie mieszkania poza nim, żeby pomóc dorosłym dzieciom w opiece nad wnukami. „Przeprowadziłam się z powrotem do Łodzi, bo wnuczka poszła do szkoły i potrzebne było, żebym była blisko i mogła dziecko odprowadzać i odbierać ze szkoły, bo rodzice pracują" (K., 65 1., miasto $\mathrm{w}$ ŁOM). Zdarza się i tak, że osoby starsze decydują się na zamieszkanie blisko dzieci, najczęściej po stracie małżonków. „Zostałem sam, żona zmarła, a tu mam córkę i czuwam teraz nad nią, a ona nade mną [...], mieszkamy bliziutko siebie (M., 79 1., średnie miasto w woj. łódzkim). Powody rodzinne koncentrujące się na chęci mieszkania blisko członków rodziny, najczęściej dzieci i wnuków, a także gotowości niesienia im pomocy bądź też korzystania $\mathrm{z}$ ich wsparcia wydają się bardzo istotnymi motywami migracyjnymi do miasta. Ta, podkreślana przez badaczy (zob. [Pawłowska 1996]) chęć mieszkania wśród „swoich”, jest istotnym czynnikiem przy wyborze miejsca zamieszkania.

Trzecia ważna przesłanka wyboru Łodzi jako miejsca do życia związana była z podjęciem w mieście edukacji na poziomie wyższym. Łódź należąca do największych w kraju ośrodków akademickich, corocznie przyciąga dziesiątki tysięcy stu- 
dentów, którzy wprawdzie w większości pochodzą z regionu łódzkiego, lecz niekiedy także z odległych obszarów Polski [Liszewski i in. 2008). Podkreślanym przez badanych powodem wyboru Łodzi jako miejsca studiowania była między innymi rekomendacja innych osób, które studiowały tu wcześniej. Uzasadnienie takie znajdujemy w wypowiedzi jednej z respondentek: „Przeprowadziłam się do Łodzi, bo moja siostra tutaj wcześniej studiowała i wynajmowała tu mieszkanie. Przyjeżdżałam do niej $[\ldots]$ pokazywała mi miasto i ja też przyjechałam tu na studia" (K, 25 1., średnie miasto w woj. kuj.-pom.). W innym przypadku wybór Łodzi podyktowany był wyborem konkretnego kierunku studiów: „Przyjechałam na studia, bo tu był kierunek, który chciałam studiować, a przy okazji zalazłam tutaj to, czego nie było u mnie [w poprzednim miejscu zamieszkania - przyp. aut.], no i zostałam" (K, 25 1., małe miasto w woj. lubelskim). Szkolnictwo wyższe jako atut miasta w opiniach studentów łódzkich uczelni zostało ukazane już w badaniach wcześniejszych [Boryczka, Sulikowski 2008]. W badaniach tych wysoko oceniano także możliwości rozrywki i kulturę, co dla młodych, studiujących osób wydaje się dużą zachęta do związania swoich losów z miastem, co najmniej na czas studiów. Centralne położenie Łodzi w sieci osadniczej kraju stanowi także istotny czynnik przy wyborze miejsca nauki. Warto podkreślić, że absolwenci łódzkich uczelni niekiedy decydują się pozostać w mieście, choć, jak wynika z badań, większość planuje jednak Łódź opuścić [Boryczka, Sulikowski 2008; Liszewski i in. 2008]. Atutem Łodzi są też niższe niż w innych dużych ośrodkach akademickich koszty utrzymania, które zdają się rekompensować skromniejsze wynagrodzenia oferowane na lokalnym rynku pracy. W opinii jednego z badanych ,Jest to miasto niedrogie do życia. I chociaż dużo się nie zarabia, to można trochę taniej żyć niż gdzie indziej” (M., 47 1., miasto poza woj. łódzkim).

Istotnymi czynnikami wpływającymi na migrację do Łodzi, które zidentyfikowano w omawianych badaniach, były także czynniki wypychające obejmujące różnego rodzaju braki i niedogodności w poprzednich miejscach zamieszkania, które zdecydowały o opuszczeniu ich przez badanych. Do najczęściej wymienianych należały:

- brak pracy (pracy w ogóle lub pracy satysfakcjonującej finansowo i/lub związanej z konkretnymi kwalifikacjami);

- brak możliwości zdobycia wykształcenia (wykształcenia w ogóle lub konkretnego kierunku i/lub poziomu wykształcenia);

- złe skomunikowanie z Łodzią i związana z tym niedogodność dojazdów do miasta (w przypadku osób już pracujących w Łodzi lub opiekujących się innymi członkami rodziny);

- brak miejsc spędzania wolnego czasu, w tym np. brak życia nocnego („,moje miasto zamierało wieczorem");

- brak oferty kulturalnej i rozrywkowej (,nuda, nic się działo, nie było gdzie wyjść");

- niedostateczna infrastruktura społeczna i usługowa w miejscu zamieszkania; 
- chęć „wyrwania się” ze wsi lub małego miasta, ze względu na brak anonimowości lub brak perspektyw życiowych.

Bliższa analiza wymienionych czynników wypychających z poprzednich miejsc zamieszkania pozwala stwierdzić, że Łódź postrzegana jest jako miasto posiadające określone zasoby decydujące o jej atrakcyjności migracyjnej. Wydaje się to być efektem przede wszystkim tego, że jako stolica regionu koncentruje wiele funkcji o charakterze metropolitalnym, które czynią ją atrakcyjną osadniczo, zwłaszcza dla osób z mniejszych ośrodków. Rozwój tych dziedzin funkcjonowania miasta, a szczególnie miejskich udogodnień (amenities) niewątpliwie będzie stanowił zachętę dla potencjalnych migrantów. Współczesne miasto ma być miejscem przyjaznym dla mieszkańców i użytkowników, których przyciąga bogata oferta wytworzonych atrakcji. Ma stać się m.in. „maszyną rozrywki” przyciągającą mieszkańców i turystów licznymi udogodnieniami, które stają się jednym z ważniejszych czynników poprawy jakości życia i jakości środowiska zamieszkania z szeroką dostępnością i różnorodnością usług oraz instytucji kultury [Clark 2004].

\section{Ocena warunków życia w Łodzi w opiniach nowych mieszkańców}

Atrakcyjność migracyjna miasta niewątpliwie jest pochodną warunków i jakości życia w nim. Jednym ze sposobów badania jakości życia jest ocena określonych dziedzin funkcjonowania miasta. Dostępność i sprawność działania takich instytucji jak służba zdrowia, instytucje edukacyjne, rynek pracy, usługi publiczne czy instytucje kultury w znacznym stopniu przesądzają o jakości życia w mieście.

Oceniając warunki życia w Łodzi, badani koncentrowali swoją uwagę na dostępności i funkcjonowaniu podstawowych kompleksów instytucjonalnych, takich jak służba zdrowia i edukacja. Ten pierwszy wskazywany był najczęściej przez ludzi starszych. Jak podkreślał jeden z respondentów: „Bardzo dobrze się żyje [...] Dobry dostęp do lekarzy specjalistów" (K, 69 1., spoza woj.). Wskazywano także na przyjazność oferty miejskiej dla seniorów: „Dobrze się żyje. O seniorów miasto zaczyna trochę dbać, robi różne akcje i trochę więcej ułatwień mamy" (K., 65 1., ŁOM). Ludzie młodzi pozytywnie postrzegali natomiast dostępność innych usług publicznych, rynek pracy, warunki mieszkaniowe oraz funkcjonowanie komunikacji miejskiej. W jednej z wypowiedzi podkreślano: „Dobrze oceniłabym kulturę i warunki mieszkaniowe, i pracę, jaką mam" (K, 23 1., woj. łódzkie). W innej percepcję warunków życia w mieście uzupełniono o pozytywną ocenę usług i transportu publicznego, co jednocześnie wpływa na rekomendację do zamieszkania w mieście dla młodych ludzi: „Żyje mi się bardzo wygodnie. Mam dostęp do sklepów, do śródmieścia szybko mogę dojechać autem albo tramwajem [...] Pracę też mam blisko, do Manufaktury też $[\ldots]$ i do ogrodu botanicznego i wszędzie. Mogłabym polecić to miasto młodym ludziom do przeprowadzki" (K, 25 1., woj. łódzkie). Pozytywnie oceniono także życie kulturalne miasta i możliwości spędzania czasu wolnego: „I kultura jest na 
dobrym poziomie, i jest gdzie pójść" (K., 25 1., spoza woj.). W ocenie warunków życia pojawiały się także wypowiedzi pozytywne, ale zarazem bardzo ogólne, które były wyrazem satysfakcji z zamieszkiwania w Lodzi i dostrzeganiem dobrych perspektyw na przyszłość. Jeden z badanych podkreśla „Dobrze mi się żyje, jestem zadowolony, miasto się rozwija i są tu duże możliwości dla ludzi” (M., 46 1., spoza woj.). Wbrew funkcjonującemu w dyskursie publicznym oraz medialnym, a popartemu także wynikami badań, negatywnemu wizerunkowi Łodzi [Michalska-Żyła 2009; Tobiasz-Lis 2013] badani podkreślali też ogólną atrakcyjność miasta: „Fajnie mi się żyje w Łodzi. Bardzo podoba mi się to miasto" (K., 27 1., spoza woj.) lub: „Dobrze mi się żyje, bo duże miasto daje duże możliwości” (M., 46 1., spoza woj.).

Negatywne oceny warunków życia w mieście koncentrowały się natomiast na wydawałoby się oczywistych mankamentach wielkomiejskiego środowiska, takich jak konieczność pokonywania znacznych odległości oraz brak integracji społecznej w miejscu zamieszkania i słabe więzi sąsiedzkie. Kwestia odległości do pokonania, choć w jakiejś mierze rekompensowana dogodną komunikacją, wskazana była przez jedną z respondentek: „Najgorsze są te odległości w mieście [...] Komunikacja jest dobra, ale te odległości przerażające" (K., 37 1., spoza woj.). Inna badana podkreśliła, że niedogodności te odczuwa szczególnie w okresie zimowym. Pozytywnie odnoszono się natomiast do funkcjonującego na terenie miasta roweru miejskiego, który postrzegany jest jako istotne udogodnienie dla mieszkańców: „W zimie jest ciężko, ale latem dobrze mi się żyje, np. teraz można korzystać z roweru miejskiego i z parków" (K., 25 1., spoza woj.).

Źródłem negatywnego postrzegania życia w mieście są także relacje, jakie panują między mieszkańcami. Swoje odczucia dotyczące stosunków sąsiedzkich w miejscu zamieszkania, jeden z respondentów wyraził następująco: „Dobrze mi się żyje, ale nie jestem przyzwyczajony do tego, że jest zero kontaktów z sąsiadami. [...] Tu każdy jest zamknięty za swoimi drzwiami [...]. Chciałbym, żebyśmy stanęli z sąsiadem, pogadali, a tu tego nie ma" (M., 79 1., woj. łódzkie). Wydaje się, że taki obraz miejskiego środowiska społecznego jest potwierdzeniem koncepcji mówiących o atrofii więzi i atomizacji społecznej, czego przejawem jest możliwy brak więzi w mikroskali sąsiedztwa [Bujwicka 2011].

Negatywne oceny odnosiły się także do struktury i zagospodarowania przestrzennego miasta i jego estetyki. Zwracano przy tym uwagę na proces zróżnicowania społeczno-przestrzennego i degradacji centralnych obszarów miasta. Jeden z respondentów tak opisał Łódź: „Miasto kontrastów, zadbane i zielone osiedla, gdzie ludzie dobrze się czują, a w centrum kamienice walą się na głowę, meliny, pijani śpią na ławkach" (M., 33 1., spoza woj.). Inny badany wyraził natomiast swój krytyczny stosunek do inwestycji realizowanych na terenie miasta i ogólnych perspektyw jego rozwoju, choć, jak sam podkreślił, jemu w Łodzi żyje się dobrze: „Generalnie żyje mi się dobrze, chociaż myślę, że to miasto zmierza ku zagładzie [...] wszędzie przebudowy i zmiany tego, co jest. A te inwestycje wcale nie dla ludzi są, tylko żeby nabić komuś kabzę" (M., 33 1., spoza woj.). 
Głosy negatywne były jednak w zdecydowanej mniejszości i często stanowiły składnik wypowiedzi o charakterze ambiwalentnym, ponieważ ich autorzy dostrzegali i wymieniali równocześnie jakieś zalety życia w Łodzi.

\section{Podsumowanie}

Analiza struktury migrantów napływających do Łodzi i meldujących się tu na stałe pokazała, że przede wszystkim są to ludzie młodzi, należący do kategorii wieku od 26 do 35 lat, a zatem osoby, których obecny etap cyklu życia szczególnie predestynuje do podjęcia decyzji o wyborze miejsca stałego zamieszkania. Co skłania ich do wyboru Łodzi? Główne powody osiedlenia się w mieście wymieniane przez osoby w tej oraz starszej grupie wiekowej (36-60 lat) można ująć w dwóch podstawowych kategoriach. Pierwsza związana jest $\mathrm{z}$ funkcjonowaniem podstawowych kompleksów instytucjonalnych, takich jak rynek pracy, edukacja, opieka zdrowotna oraz jakość usług dla ludności w tym możliwości zaspokojenia potrzeb kulturalnych i zagospodarowania czasu wolnego. Dostępna i dobrze funkcjonująca infrastruktura społeczna i relatywnie dobrze oceniany rynek pracy uzupełnione o udogodnienia i atrakcje miejskie są postrzegane jako główne walory Łodzi i czynniki wzmacniające jej atrakcyjność dla migracji. Drugą, nie mniej ważną, kategorię powodów wyboru Łodzi stanowią względy osobiste i rodzinne, wśród których dominowało znalezienie partnera życiowego pochodzącego z Łodzi.

Badania pokazały, że warunki życia w mieście wydają się nie rozczarowywać badanych, bowiem są oni na ogół zadowoleni z życia w nim i je pozytywnie oceniają. Niektórzy jednak zwracają uwagę na widoczne zróżnicowanie społeczno-przestrzenne Łodzi i jej zaniedbanie. Zwracano także uwagę na nie najlepsze perspektywy rozwojowe miasta, choć opinie przeciwstawne prognozujące dobrą przyszłość dla Łodzi pojawiały się równie często. Można zatem stwierdzić, że w tej ostatniej kwestii odnotowano raczej ambiwalencję postaw.

Przedstawiciele kolejnej kategorii nowych łodzian, obejmującej osoby między 19. a 25. rokiem życia, czyli rozpoczynające swoje samodzielne życie, wybierali Łódź przede wszystkim w związku z podjęciem studiów na jednej z łódzkich uczelni lub też znalezieniem tutaj pierwszej pracy. Dowodzi to oczywistej i wielokrotnie zweryfikowanej tezy, że najlepszym gwarantem zatrzymania młodych ludzi kończących edukację jest możliwość znalezienia przez nich satysfakcjonującej pracy. Wśród uzasadnień wyboru Łodzi pojawiały się zatem w głównej mierze te związane z jakością tutejszych uczelni, jakością i dostępnością poszukiwanych kierunków studiów oraz możliwością podjęcia pracy odpowiadającej kompetencjom. Ponadto w tej grupie wiekowej wskazywano na bogate życie kulturalne miasta, dobrze rozwiniętą sferę rozrywki i możliwości spędzania czasu wolnego jako istotne czynniki jego atrakcyjności.

W grupie migrantów najstarszych obejmującej osoby powyżej 60. roku życia główne przyczyny osiedlenia się w mieście bądź powrotu do niego po latach za- 
mieszkiwania w innych miejscach koncentrowały się natomiast na względach rodzinnych. Chęć zamieszkania blisko dzieci, wnuków i związana z tym chęć niesienia im pomocy, a także korzystania z ich wsparcia na starość były podstawowymi motywami przeprowadzki seniorów do Łodzi. Istotnym atutem miasta $\mathrm{w}$ ich ocenie była przede wszystkim dostępna i dobrze funkcjonująca służba zdrowia, a także poprawiająca się oferta miejskich atrakcji i udogodnień dedykowanych tej części miejskiego społeczeństwa. Jest to tym bardziej ważne, że w niedalekiej przyszłości grupa ta będzie stanowiła bardzo znaczącą kategorię mieszkańców miasta.

\section{Literatura}

Besser T.L., Recker N., Parker M., 2009, The impact of new employers from the outside, the growth of local capitalism, and new amenities on the social and economic welfare of small towns, Economic Development Quarterly, vol. 23, no. 4, s. 306-316.

Boryczka E., Sulikowski T., 2008, Wizerunek miasta w oczach studentów tódzkich uczelni publicznych - podstawy teoretyczne, [w:] Przygodzki Z., Sokołowicz M.E. (red.), Nowoczesne miasto. Badania, instrumenty, analizy, Wydawnictwo Biblioteka, Łódź, s. 231-236.

Brehm J., Eisenhauer B., Krannich R., 2004, Dimensions of community attachment and their relationship to well-being in the amenity-rich rural west, Rural Sociology, vol. 69, s. 405-429.

Bujwicka A., 2011, Typy wielkomiejskiego sasiedztwa. Wyobrażone a praktykowane stosunki sasiedzkie mieszkańców Łodzi, Acta Universitatis Lodziensis. Folia Sociologica, nr 36, s. 101-119.

Clark T.N., 2004, The City as an Entertainment Machine, Elsevier, Oxford.

Czapiński J., Panek T. (red.), 2015, Diagnoza społeczna 2015. Warunki i jakość życia Polaków. Raport, Rada Monitoringu Społecznego, Warszawa.

Florida R., 2002, The Rise of the Creative Class, Basic Books, New York.

Górny A., Kaczmarczyk P., 2003, Uwarunkowania i mechanizmy migracji zarobkowych w świetle wybranych koncepcji teoretycznych, Prace Migracyjne, nr 49, Instytut Studiów Społecznych UW, Warszawa.

GUS, 2002, Bezrobotni oraz stopa bezrobocia wg województw, podregionów i powiatów - styczeń-grudzień 2002, https://stat.gov.pl/obszary-tematyczne/rynek-pracy/bezrobocie-rejestrowane/liczbabezrobotnych-zarejestrowanych-oraz-stopa-bezrobocia-wedlug-wojewodztw-podregionow-ipowiatow-stan-w-koncu-grudnia-2015-r-,2,40.html?pdf=1.

GUS, 2014, Miasta w liczbach 2012, GUS, Urząd Statystyczny w Poznaniu, Warszawa.

Hugo G., 1982, Circular Migration in Indonesia, Population and Development Review, vol. 8, no. 1, s. $59-83$.

Kałuża-Kopias D., 2010, Migracje wewnętrzne $w$ Łodzi na tle wybranych, największych miast $w$ Polsce, Acta Universitatis Lodziensis. Folia Sociologica, nr 35, s. 199-217.

Kałuża-Kopias D., 2014, Atrakcyjność migracyjna wielkich miast. Stan obecny i perspektywy, Problemy Polityki Społecznej nr 4 (27), s. 41-54.

Kryńska E., 2015, Znikanie miast. Studium przypadku Łodzi, Studia Ekonomiczne. Zeszyty Naukowe Uniwersytetu Ekonomicznego w Katowicach, nr 223, s. 174-185.

Kupiszewski M., 2002, Modelowanie dynamiki przemian ludności w warunkach wzrostu znaczenia migracji międzynarodowych, IGiPZ PAN, Warszawa.

Landry C., Bianchini F., 1995, The Creative City, Demos, London.

Lee, E., 1966, A theory of migration, Demography, vol. 3, no. 1, s. 47-57. 
Liszewski S., Szafrańska E., Wolaniuk A., 2008, Szkolnictwo wyższe Łodzi i jego rola w rozwoju funkcji metropolitalnej miasta, Łódzkie Towarzystwo Naukowe, Łódź.

Łabędzki H., 2009, Migracje ludności na obszarach przygranicznych poludniowo-zachodniej Polski, Biblioteka Regionalisty, nr 9, s. 7-15.

Michalska-Żyła A. 2009, Wizerunek miasta poprzemysłowego. Przykład Lodzi, [w:] Dymnicka M., Majer A. (red.), Współczesne miasta. Szkice socjologiczne, Wydawnictwo Uniwersytetu Łódzkiego, Łódź, s. 127-144.

Michalska-Żyła A., 2014, The quality of life and social capital in post-industrial peripheral cities, Przegląd Socjologiczny, t. LXIII/1, s. 109-136.

Pawłowska K., 1996, Idea swojskości w urbanistyce i architekturze miejskiej, Seria: Architektura, Monografia, 203, Kraków.

PWC, 2011, Raport o polskich metropoliach: 2011, www.pwc.com.pl (10.01.2018).

PWC, 2015, Raport o polskich metropoliach: 2015, www.pwc.com.pl (10.01.2018).

Szukalski P., 2012, Sytuacja demograficzna Łodzi, Wydawnictwo Biblioteka, Łódź.

Tarasiewicz P., 2013, Migracje a drenaż mózgów, Człowiek w Kulturze, 23, Fundacja Lubelska Szkoła Filozofii Chrześcijańskiej, s. 145-160.

Tobiasz-Lis P., 2013, Zmiany wyobrażeń mieszkańców Łodzi o przestrzeni miasta, Wydawnictwo Uniwersytetu Łódzkiego, Łódź. 